\author{
Eliza Farelnik \\ University of Warmia and Mazury in Olsztyn \\ e-mail: eliza.farelnik@uwm.edu.pl \\ ORCID: 0000-0002-8961-3561
}

\title{
DETERMINANTS OF THE DEVELOPMENT OF SLOW CITIES IN POLAND
}

DOI: $10.15611 / \mathrm{pn} .2020 .7 .02$

JEL Classification: O19, O20, O21

(C) 2020 Eliza Farelnik

This work is licensed under the Creative Commons Attribution-ShareAlike 4.0 International License. To view a copy of this license, visit http://creativecommons.org/licenses/by-sa/4.0/

Quote as: Farelnik, E. (2020). Determinants of the development of slow cities in Poland. Prace Naukowe Uniwersytetu Ekonomicznego we Wrocławiu, 64(7).

\begin{abstract}
The aim of this study was to identify the factors, determinants and barriers in the development of slow cities in Poland, with special attention paid to those connected with specific features of the slow city model and membership in the Cittaslow network. The research subject was the factors and determinants of the development of member cities of the Polish National Cittaslow Network. All analyses and conclusions were mainly based on a critical examination of the literature. An identification of determinants and factors involved in the development of slow cities in Poland was made, including the division of them into local, regional, national, international and global categories. Attention was drawn to the determinants of implementing the slow city model connected with the contemporary paradigm of the development of cities, which should be considered in the management of slow cities in Poland.
\end{abstract}

Keywords: Cittaslow, slow city, determinants of development, small cities.

\section{Introduction}

The local policy of urban development, focused on the improvement of the quality of life or higher competitiveness of a city, employs different models and concepts of development (such as smart city, green city, slow city). City authorities enter into cooperation with other urban centres, nurturing relationships with partner cities or joining various associations, unions or networks of cities. Moreover, over the last two decades, urban networks have demonstrated a range of different ways of establishing, developing and maintaining partnerships and collaboration among cities and local authorities. 'Active cities' are generally involved in more than one network. These 
cities show a strong 'aptitude for urban networking', often belonging to different national circuits, both European and international (Atkinson and Rossignolo, 2010, pp. 198-199). Global or regional networks of collaborating communities, building economic activity that has global reach from the community assets and regional network, generating jobs within communities that match or such matches can be created for the local population, these are the main features of the new model of urban economic development (Blakely, 2009, p. 57). Thus the development of cities primarily depends on the implemented development model, and on relationships built within the network of which a given city is a component (node, member).

An example illustrating these two processes in small towns is when the principles underlying the slow city model are adopted as important guidelines for a city, in connection with its membership in the network of cities adhering to the similar philosophy of development (model of development), that is the Cittaslow International grid.

The aim of this study was to identify main development factors, determinants and barriers in the growth of slow cities in Poland, with special attention paid to those which are associated with the slow city model and the Cittaslow network (and not just arising from the fact of being a small town in Poland). The research subject was the factors and determinants of the development of member cities of the Polish National Cittaslow Network. All analyses and conclusions were mainly based on a critical survey of the literature. This article represents a theoretical approach to the problem and may be a starting point for further analysis of local, regional and national determinants of the development of Cittaslow cities, using adequate quantitative methods (e.g. methods based on a diagnostic survey) and qualitative ones (statistical inference methods). The author has also referred to conclusions drawn from her previous studies into the functioning of Cittaslow cities in Poland.

\section{Factors, determinants and barriers of local development}

Local development is a very complex process, and its complexity is due to several reasons: diversity of territorial units it may apply to (e.g. cities, rural communes), a variety of aims that the planned development should fulfil, and the various policies and measures which affect it. J.J. Parysek (1997, pp. 46-52) claims that 'local development is associated with the local scale of social and economic activities, and it encompasses the local environment in which a given community lives. Local development is implemented with the view of the needs of local communities, local development resources, and the involvement of local communities, local authorities, as well as other organisations and institutions, mainly non-commercial (nonprofit) ones.' Meanwhile, L. Wojtasiewicz (1996, pp. 99-112) underlines that local development is 'a complex of qualitative transformations affecting a given area and concerning the level of living of the community and conditions in which business enterprises located in this area operate.' 
Local development is also affected by a variety of factors, determinants and barriers. A factor is understood as a thing having influence on the state of matters, an event (a change in the state of matters) or a process which is inherent in this thing, event or process, directly stems from thereof or is located in their immediate environment. In other words, it is the cause, endogenous in its nature and direct in the influence it generates, of a change in the properties of a thing, event or process, which occurs in a specific place and at a specific time (time period). The presence of a factor means facing an internal, endogenous cause of a specific state of matters, an event (a change in this state of matters) or a concrete process. The absence of causes (factors) is often interpreted as the appearance of barriers, limitations or drawbacks to possible changes and to their development (Parysek, 2018, p. 46).

Determinants of development are understood as circumstances external to a thing, event or process that have influence on observed changes. In other words, a determinant is an instance of the circumstances which are exogenous relative to the subject in question and the given place that are beneficial to the ongoing change but whose influence is not, at least not directly, connected with this subject and its properties (object, place and their properties). The developmental factors are most often deterministic in character and almost always yield to steering, whereas determinants tend to be stochastic in character and therefore any possibility of controlling them are minimal (Parysek, 2018, p. 47).

According to Bagdziński (1994, p. 17), the factors of local development can be divided into external and internal factors. For example, external factors include exogenous conditions such as global, local and regional conditions of local development; arising from the state's economic policy and the regional and global environment of a territorial unit. Internal factors include endogenous components that are rooted in the local system, by definition (see: Table 1). In addition, he also distinguished hard factors (quantitative) and soft factors (qualitative).

When trying to identify the factors stimulating the process of local development, attention should be paid to barriers as well, that is the factors which appear in inadequate (excessive or insufficient) quantities, are of the wrong quality or distribution, give rise to attempts to adapt to them or counteract them (Kosiedowski, 2005, pp. 26-27). Maik and Parysek (1978, pp. 32-57) discussed several classifications of barriers, where the distinguishing features are: the character of limitations (quantitative, qualitative, structural and functional barriers), mutual dependences between socio-economic phenomena (elementary and complex barriers), type (natural, demographic, economic, social, organisational and institutional barriers), level in the hierarchy of local settings (local, regional, national, international and global barriers), temporal dimension (potential barriers that may exist, temporary barriers, single-event barriers and permanent ones), and the way they appear and affect the surroundings (deterministic and stochastic barriers). Barriers can originate from internal sources, rooted in the local system, or external, induced by the regional or global environment, i.e. macroeconomic barriers. Internal barriers 
Table 1. Local development factors

\begin{tabular}{|c|c|c|}
\hline $\begin{array}{c}\text { Factors } \\
\text { of development }\end{array}$ & Internal factors & External factors \\
\hline $\begin{array}{l}\text { Political and } \\
\text { state system } \\
\text { factors }\end{array}$ & $\begin{array}{l}\text { the way the authorities exercise } \\
\text { power (relations between local } \\
\text { authorities and society) } \\
\text { the extent to which the local } \\
\text { authorities are accepted by the } \\
\text { society }\end{array}$ & $\begin{array}{l}\text { - character of the authorities (the state } \\
\text { system) } \\
\text { - the scope of competences (competences } \\
\text { of authorities on different levels) } \\
\text { the extent to which municipalities are } \\
\text { independent and self-governed }\end{array}$ \\
\hline Social factors & $\begin{array}{l}\text { - needs, values and aspirations of } \\
\text { residents, local actors } \\
\text { - attitude to reforms, innovations } \\
\text { and technological progress } \\
\text { - creativity and entrepreneurship }\end{array}$ & $\begin{array}{l}\text { supra-local characteristics of the } \\
\text { society (in Poland seen as post-partition } \\
\text { characteristics) } \\
\text { culture, traditions of a broader } \\
\text { territorial setting }\end{array}$ \\
\hline $\begin{array}{l}\text { Economic } \\
\text { factors }\end{array}$ & $\begin{array}{l}\text { - technical, economic and social } \\
\text { infrastructure } \\
\text { - economic potential, local capital } \\
\text { and investments }\end{array}$ & $\begin{array}{l}\text { - economic condition of the country, rate } \\
\text { of inflation } \\
\text { - rate of unemployment } \\
\text { - external capital and investments }\end{array}$ \\
\hline Spatial factors & $\begin{array}{l}\text { - } \text { natural resources } \\
\text { - } \text { natural environmental assets } \\
\text { - } \text { the city's landscape }\end{array}$ & $\begin{array}{l}\text { - supra-local environmental conditions } \\
\text { - ecosystems transcending the borders } \\
\text { of a municipality }\end{array}$ \\
\hline
\end{tabular}

Source: (Chądzyński, 2007, p. 85).

include infrastructural barriers, the poor condition of the natural environment, the poor economic standing of the businesses located in each municipality, low quality social capital, the low level of the development of civic society, etc. The external barriers are: the difficult economic situation of the country or region, unfavourable legal regulations in each country, etc.

The determinants of local development are political, economic, social, natural, legal, those connected with the image and public relations, and others (Table 2). These determinants may emerge and appear in the territory of a given unit (internal, endogenous determinants) or in the external environment (exogenous determinants).

Furthermore, Parysek (2018, pp. 48, 52), emphasised that for something to be treated as a factor, it needs to satisfy certain conditions and must not be considered as a determinant. Categories of factors and determinants can be analysed in terms of the way they produce influence. For example, they may have a direct or indirect influence, and they may have a specific character of influence; external (exogenous) or internal (endogenous). It is therefore possible to distinguish internal (endogenous) and external (exogenous) development factors, which have a direct influence on the development of internal (endogenous) and external (exogenous) developmental determinants. It is also possible that these may have an indirect influence on local development. 
Table 2. Basic categories of determinants in socio-economic development

\begin{tabular}{|c|c|}
\hline $\begin{array}{c}\text { Category } \\
\text { of determinants }\end{array}$ & Explanations \\
\hline Political & $\begin{array}{l}\text { Political situation in the world, country, region, municipality (town); political } \\
\text { stability and the stability of authorities; protectionism; geopolitical situation; } \\
\text { position in the political system of the world and region (continent); the policy } \\
\text { of political and economic international structures; international tension and political } \\
\text { conflicts; internal political conflicts, etc. }\end{array}$ \\
\hline Economic & $\begin{array}{l}\text { Economic situation in the world, region and country; the state's economic situation and } \\
\text { policy; the economic situation and policy of international structures (organisations, } \\
\text { unions, blocks, agreements, etc.); stability of economies and the financial situation } \\
\text { (budget) of the country, region and municipality (city); international economic } \\
\text { cooperation; competition between economies (competitiveness), diffusion and } \\
\text { possibilities of introducing technological innovations; conditions, level and } \\
\text { outcomes of the economic cooperation between member countries (e.g. EU states), } \\
\text { countries, regions, municipalities, etc. }\end{array}$ \\
\hline Social & $\begin{array}{l}\text { Uncontrolled social processes (demographic processes, migrations, urbanisation, } \\
\text { pathologies); the state's social policy and its approval by the society; internal social } \\
\text { tensions and conflicts; adopted systems of values, models of life and consumption } \\
\text { as well as their modifications; the social climate for development; level of social } \\
\text { activity. }\end{array}$ \\
\hline Natural & $\begin{array}{l}\text { Climate change; changeable and unpredictable weather events; catastrophic } \\
\text { atmospheric and seismic events and their consequences; the environmental policy } \\
\text { of international organisations and associations; level of ecological awareness in } \\
\text { societies and communities. }\end{array}$ \\
\hline Legal & $\begin{array}{l}\text { Legal regulations on all levels which favour development; stable law; degree of legal } \\
\text { autonomy; obligations as members of international organisations and associations, } \\
\text { with various degrees of consequences; local laws. }\end{array}$ \\
\hline $\begin{array}{l}\text { Associated } \\
\text { with the image }\end{array}$ & $\begin{array}{l}\text { Perception of the country, region and municipality by investors; assessment } \\
\text { of the situation in the country, regions and cities by financial institutions and rating } \\
\text { agencies as well as different ranking lists; promotion of the country, region and } \\
\text { municipality (visits, fairs, exhibitions, shows, published materials), marketing } \\
\text { events and their effectiveness; the image of the country, region and municipality } \\
\text { shaped by the political opposition, competitors, media and tourists, etc. }\end{array}$ \\
\hline Others & $\begin{array}{l}\text { Terrorist threat; the need to counteract terrorism and costs involved; military } \\
\text { conflicts and their aftermath, errors made during elections and failed obligations; } \\
\text { other random situations. }\end{array}$ \\
\hline
\end{tabular}

Source: (Parysek, 2018, p. 53).

\section{Pillars of slow city development}

Korenik (2013, p. 38) drew attention to the reorientation of local socio-spatial structures, where local communities become actively engaged in processes occurring in the world undergoing globalisation. This reorganisation, which considers specific 
local values, leads to a greater sense of being an actor within local communities, which therefore allows residents to assume more responsibility for the fate of their local territorial unit (city, municipality, rural commune). This is achieved by elaborating new models of local development.

An example of a development model is the slow city concept. This concept responds accurately to the needs of local communities, such as the rhythm of work and life which is in agreement with nature rather than being excessively busy, or an improved quality of life in a city. Moreover, this model plans the development of a local territorial unit based on its endogenous resources; especially social and cultural capital. This concept of the development of a city is being implemented by many cities in Poland and across the world.

The origin of the international network known as Cittaslow is connected with the growing popularity of the Slow Food movement and the initiative undertaken by mayors of four small Italian cities: Bra, Greve in Chianti, Orvieto and Positano. These mayors identified an opportunity for the development of their cities in this philosophy and model of urban living. The word Cittaslow originates from two words: Italian 'cittá', meaning a city, and the English word 'slow'. The organisation 'Cittaslow - an international network of cities where living is good' was founded on 15 October 1999 in Orvieto, Italy. The association is a non-profit organisation, whose goal is to promote and disseminate 'the culture of good life' and to implement solutions which should improve the quality of life in cities (Cittaslow International Charter, 2017, p. 5). The association can be joined by ordinary members (cities with a population of no more than 50 thousand) and supporting members (e.g. provinces, municipalities, metropolises, unions of municipalities). The association's organs are: President, International Assembly, International Coordinating Committee, Board and International Science Committee. The Cittaslow Network can be supported by so-called Cittaslow friends, i.e. associations, commerce chambers, and companies in the industrial, service, tourism and hospitality or agricultural sectors of the economy.

Member cities are first admitted to the Cittaslow International Network and afterwards, when the minimum required number of cities in a given country is reached, they create a national Cittaslow network (such as the Polish National Cittaslow Network). The Cittaslow International Network nowadays consists of 264 cities from 30 countries (Cittaslow List, 2019). Currently, there are 20 national networks around the world. Most of the member cities are now in Italy (84), Poland (31), Germany (21), Turkey (17), South Korea (16), China (12), the Netherlands (11) and France (10). In order to join the Cittaslow network, a candidate city must go through a certification process and satisfy at least a $50 \%+1$ assessment criteria, divided into seven key areas: energy and environmental policies, infrastructure policies, quality of urban life policies, agricultural touristic and artisan policies, policies for hospitality, awareness and training, social cohesion, and partnerships (Międzynarodowy statut..., 2017, pp. 22-25). 
In Poland, the Cittaslow network began to develop in 2004, when Reszel joined the international network of slow cities. Then, Bisztynek, Biskupiec and Lidzbark Warmiński became members, making it possible to set up the Polish National Cittaslow Network in 2007. All the founder cities of the Polish National Cittaslow Network lie in the Province of Warmia and Mazury (województwo warmińskomazurskie). Today, there are 18 more slow cities in this province (Barczewo, Bartoszyce, Braniewo, Dobre Miasto, Działdowo, Gołdap, Górowo Iławeckie, Jeziorany, Lidzbark, Lubawa, Nidzica, Nowe Miasto Lubawskie, Olsztynek, Orneta, Pasym, Ryn, Sępopol, Wydminy). Other members of the Polish network are Głubczyce and Prudnik (województwo [voivodeship] opolskie), Kalety (ślaskie), Murowana Goślina (wielkopolskie), Nowy Dwór Gdański (pomorskie), Rejowiec Fabryczny (lubelskie), Rzgów (tódzkie), Sianów (zachodniopomorskie) and Sierpc (mazowieckie).

The cities in the Polish network are diverse not only in the size of their population, but also in their population density, their situation in the labour market, or their level of social and economic development (Wierzbicka, 2020, pp. 217-218; Wierzbicka, Farelnik, and Stanowicka, 2019, p. 121). The main areas of cooperation between Cittaslow cities in the Polish network are promotion of the city, tourism, culture, sport, recreation, management, spatial economy, environment protection, local enterprise and education. The cooperation of small cities allows them to achieve many positive social, economic, and spatial effects. The permanent cooperation of cities in the Cittaslow network is an opportunity for the development of small cities in Poland.

There are seven pillars on which the concept of a slow city, and consequently the development of Cittaslow cities (also in Poland), rests on:

1. Deceleration and the quality of living - associated with living in accord with natural rhythms, time for development, socialising, appreciation of culture, nature and local cuisine, while simultaneously taking advantage of contemporary technological achievements to improve the quality and accessibility to the broadly understood urban product (see: Honore, 2005; Szołtysek, 2018).

2. Local culture and heritage - making deliberate use of the local, endogenous resources, mostly social and cultural. Local cultural resources and historical heritage form the basis for shaping the local identity of residents, which explains why it is recommended to protect and develop cultural (tangible and intangible) heritage, such as local traditions, architecture, cuisine, and identity, together known as a city's genus loci (cf. Murzyn-Kupisz, 2012, pp. 80-85).

3. Social justice - the development of a city is achieved in compliance with the principles of equality, respect and social justice as well as paying attention to the needs of future generations (inter-generational fairness).

4. Circular economy - striving towards a reduction of waste in manufacturing processes and in agriculture, the organisation of production processes in a closed cycle, promoting smart consumption and recycling, which are a duty rather than 
a choice made by an aware citizen. From a broader perspective, it becomes evident that there is a necessity in cities to make a transition from a linear economy to a circular economy, understood as something more than an economy in a closed cycle (Hausner, 2019, pp. 237, 295-302).

5. Sustainable development - the policy of urban development in slow cities relies on the paradigm of sustainable development, where the social, economic, spatial and environmental spheres are taken into consideration. The search for certain equilibrium can also be applied to relations between past, present day and future, which in the philosophy of Cittaslow is evident (Pink and Seale, 2017, pp. 194-196). Such an approach is characterised by a high degree of awareness, manifested for example in the conservation of one's historical heritage, in efforts to attain a high quality of living for the city's inhabitants, responding to their needs, and in a clearer vision of the town's future (sustainable, smart, resilient, and fair).

6. Cooperation and networking are two processes without which the development of cities would be impossible. On the one hand, there is collaboration on the local level - creativity, participation, engagement on behalf of inhabitants and local subjects; on the other hand, this means cooperation between local authorities who are willing to build collaborative relationships between other cities in a network. Such co-occurrence of collaboration and competition between cities (for example, competing for EU funds) is referred to as coopetition of territorial units. It is worth underlining that networks of cities are groups of urban centres within which the transfer of goods, persons and ideas is possible (Glaeser, Ponzetto, and Zou, 2015, p. 11). In particular, shared ideas and values are an immanent trait of slow cities.

7. Resilience - this concept can be useful in the management of a city, the aim of which is to handle better any crisis situations or external, unexpected shocks. A higher level of urban resilience means that a city can overcome a crisis better and more quickly and return to the prior situation. Local entrepreneurship developed on the basis of a city's endogenous resources can be one of the key elements creating a 'resilient local economy' (see: Carp, 2012a, pp. 169-172; Carp, 2012b, pp. 99-126; Leigh and Blakely, 2013; pp. 425-434, Strzelecka, 2018, pp. 121-130).

When analysing the determinants underlying the functioning of the Polish National Cittaslow Network, it is recommended to refer to both the pillars and major principles of the movement itself, and to the specific character of Polish mediumsized and small cities which belong to the network. Therefore the list of factors, determinants and barriers for the development of slow cities is very long and diverse.

\section{Factors, determinants and barriers for the development of slow cities in Poland}

The factors, determinants and barriers for the development of cities - members of the Cittaslow network can be divided into those which generally apply to the specific situation of small and medium cities in Poland, and those which can be specifically 
attached to the developmental model of a slow city, adopted by all cities associated in the Cittaslow network. As to the former, the general catalogue of factors and determinants in the development of cities in Poland is relatively well described in the literature (see: Churski, 2008, pp. 50-52; Hryniewicz, 2017, pp. 5-23; Jałowiecki, 1989; Parysek, 2018, pp. 37-56; Sztando, 2017, pp. 110-116; Wojtasiewicz, 1997, pp. 7-18), the author will focus on the latter category of determinants specific for 'slow cities' (cf. Mazur-Belzyt, 2014, pp. 39-44).

Attention should be paid in any analysis of factors influencing the development of Cittaslow member cities relative to the determinants of the implementation of the slow city model, arising from the paradigm of the development of contemporary cities (Figure 1.). This paradigm consists not only in the concept of sustainable development of cities, but also in the notions of a smart city, urban resilience, a competitive city, a just city, and a cooperating network city (see: Mierzejewska, 2009, pp. 115-121, 180-224; Drobniak 2015, pp. 119-129; Sikora-Fernandez, 2013, pp. 83-88; Sikora-Fernandez, 2018, pp. 52-59; Tocci, 2018, pp. 118-120). The merger of different concepts and approaches is an example of the process of hybridisation, which in the case of Cittaslow network cities can be reflected in the development of the model called 'smart slow city' (Farelnik, 2018, pp. 142-144).

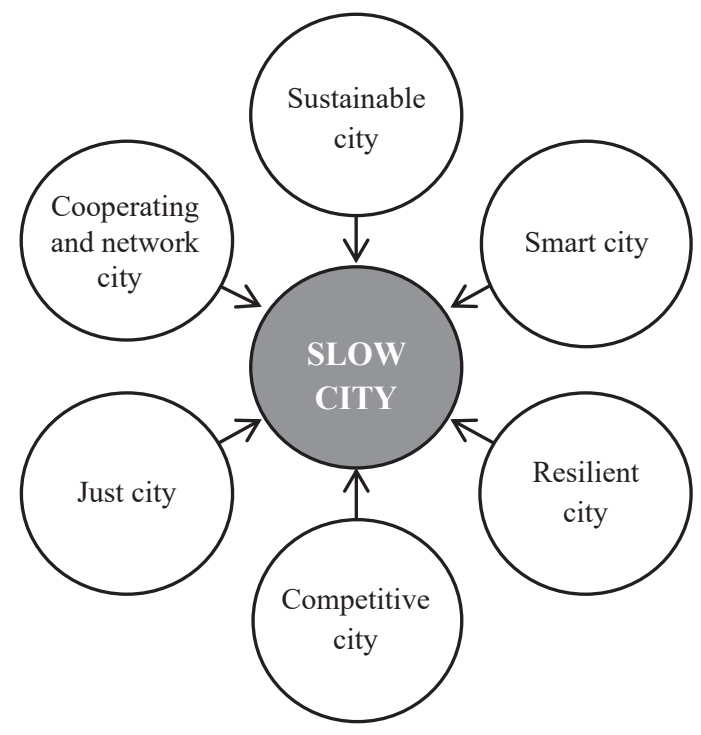

Fig. 1. Paradigm of slow city development

Source: own elaboration.

The factors and determinants in the development of slow cities can be classified according to levels, such as local (a city or municipality), regional, national, international and global. 
On a local level, attention should be paid to the following factors with the internal (endogenous) character (cf. Farelnik, 2018, pp. 137-146; Farelnik, 2020, pp. 267-287; Jaszczak, Morawiak, and Żukowska, 2020, pp. 19-20; Ponadlokalny program rewitalizacji..., 2019, pp. 44-45):

- terms of local governments, which affects the permanence (or its lack) of the ongoing development policy stemming from the adaptation of the slow city model;

- active stance, determination of authorities and local leaders to implement the vision of 'a city where life is good';

- priorities in the city's investment policy and spatial management in line with the development in the spirit of a slow city - respect for the local (material and non-material) cultural heritage, support for local creators, revitalisation, social and economic activisation, directed towards the development of such areas as tourism, local trade and services;

- cultural policy focusing on promoting and nurturing the cultural heritage and products of local culture, respecting the so-called genius loci, spirit of the place;

- awareness and the policy to protect and conserve the natural environment, local natural resources, in line with the paradigm of sustainable development and a circular economy;

- knowledge of the philosophy of slow, and the approval of and identification with the concept of developing the city in the spirit of slow city among the inhabitants;

- level of entrepreneurship among the city residents, which may rely on the production of goods and the provision of services drawing on the local tradition and cultural heritage while developing slow tourism;

- hospitability, openness and tolerance of residents of a city;

- the degree of development of a civic society, social participation and involvement in the process of governance of the city;

- well-developed sense of local identity.

Local factors of an external (exogenous) character include external sources of funding dedicated to projects performed in Cittaslow cities, such as EU funds allocated to revitalisation of cities which belong to the network (Ponadlokalny program rewitalizacji..., 2019), and which directly contribute to their development. It is worth noting the work done by the Polish Association 'Polish Cittaslow Cities', which is now busy coordinating the execution of the trans-local revitalisation programmes, but whose tasks may evolve in the future.

Regional and national factors (external) include (see: Batyk and Woźniak, 2019, pp. 56-67; Farelnik, 2019, pp. 130-135; Galibarczyk, 2017, pp. 110-122):

- support given by the so-called 'supporting members' and 'Cittaslow friends' active in the country and the region. For instance, ever since its foundation, the Polish National Cittaslow Network has been supported by the Marshal's Office of Warmińsko-Mazurskie Voivodship in Olsztyn. In 2019, another supporting member was appointed, namely the District of Olsztyn, while the Szynaka 
Furniture Company, which has branches in three Cittaslow cities in Warmia and Mazury, was nominated as a Cittaslow friend, the first one in Poland;

- knowledge and popularity of the ideas of Cittaslow and slow living in the region and in the entire country;

- a regional policy that highlights the important role of Cittaslow cities in the region. For example, the Strategy for the development of tourism in the Province of Warmia and Mazury until the year 2025 (Strategia rozwoju turystyki..., 2016, p. 43) specifies that Cittaslow cities are one of the four image products of the region, while the Regional Operational Programme of the Voivodeship of Warmia and Mazury 2014-2020 contains a plan to support the revitalisation of cities which belong to the Cittaslow network;

- promotion of the slow city development model on the nationwide level - in line with the National urban policy 2023 (Krajowa polityka miejska 2023, 2015, p. 101), using some elements of the slow city concept, such as creating the image of a city that takes special care in all aspects supporting a high quality of life: quality of the natural environment, attractiveness and accessibility of space, promoting regional products, development of the infrastructure giving preference to pedestrian and cycle traffic, which can set a new pathway in the development of cities;

- development of collaboration between cities that belong to the Cittaslow network in regions and countrywide, in connection with the performance of shared promotional and cultural activities, and the exchange of good practice examples, which serve the functions of a protector city during the certification process. In a broader sense, it is possible to refer to the coopetition of cities in the Cittaslow network (simultaneous cooperation and competition of cities), which is a response to the competition among cities on a regional and national scale;

- the work carried out by the Science Committee of the Polish National Cittaslow Network, which may integrate academic communities (and others as well) around the issues of the development of the Cittaslow movement. They may also present research results, propose recommendations, be active and enter into collaboration with regional and national entities in order to provide substantive support to the Cittaslow member cities;

- the management system in the national network of cities, and the creation of supra-local urban products - a supra-local perspective of planning the processes of urban revitalisation, measures to shape the networked product for tourism, promotion and the creation of a positive image for the Cittaslow network (in the country and in the region).

Determinants with an international and global (external) character with regards to the Cittaslow cities are as follows (see: Sung and Hoo, 2019, pp. 121-125; Zawadzka, 2017, pp. 90-106):

- activities undertaken by organs of the International Cittaslow Association; 
- the policy of limiting/decelerating or accelerating the growth in a number of cities within the Cittaslow network globally, implemented by Cittaslow International;

- requirements for certification and so-called re-certification, approved by the international organs of the Cittaslow network;

- the actions pursued by the International Science Committee of the Cittaslow Network (integration and inspiration);

- the popularity of the slow philosophy and the Slow Food movement around the world, as well as the spread of similar concepts; for example LOHAS (Lifestyle of Health and Sustainability), which is popular in China;

- the image and promotion of the Cittaslow Network in the world;

- global trends in world tourism (slow tourism, slow traveling);

- the policy of the development of cities implemented on the EU level (admitting the role of the Cittaslow Network of small cities);

- global competition between cities (competition with bigger cities, implementing a different model of development; specialisation of Cittaslow small cities);

- rapid growth of technologies and pressure to be innovative, both leading to the evolution of the slow city model towards the 'smart slow city' one;

- global crises and threats (terrorism, economic crises, pandemics, natural disasters, etc.);

- the adaptation of the slow city model and building networks of small cities around the world is a certain global trend, which responds to the needs to local communities in such matters as: protection of endogenous cultural resources of cities, building social bonds and identity as residents of a city, and participation in the development of one's place of living (improved quality of life);

- the need to acknowledge 'the voice' of smaller cities in the international arena and on a global scale (lobbying of small cities in the EU).

It is also worth noting certain barriers which may hinder or even halt the development of slow cities and the Cittaslow network in Poland. In particular, the following barriers should be mentioned (cf. Gruszecka-Tieśluk, 2013, pp. 383-393; Yurtseven and Kaya, 2011, pp. 91-98; Zadęcka, 2017, pp. 159-172):

- the reluctance of inhabitants and authorities to consider the slow city concept and consequently their less active participation in the implementation of the adopted vision of the city's development;

- terms of office set for the authorities, and hence the risk of discontinuation of the current policy;

- a decrease in the popularity of the slow philosophy and the Cittaslow Network in favour of other models of cities, e.g. the smart city, and the growing popularity of alternative forms of tourism (other than slow tourism);

- growing consumerism in the society and the increasing popularity of other patterns of culture, contradictory to the assumptions of the slow philosophy;

- the literal understanding of the protection of a city's cultural heritage and the associated risk of turning a city into a Skansen-like site, which entails its stagnation; 
- the lack of a clear vision and specialisation of a Cittaslow city, as stemming from the adaptation of the slow city concept to the individual needs of a small city;

- the municipal budget (limited funds which can be allocated to promotional or cultural activities, infrastructural investments or the membership fee payable to the international association Cittaslow International, also unequal support to Cittaslow cities from EU funds under the framework of the Regional Operational Programmes in Poland);

- the large distance from one city to other member cities of the Polish National Cittaslow Network (the lack of results arising from proximity);

- difficulties in coordination of a large and dispersed network of cities;

- insufficient activity of supporting members of the Polish National Cittaslow Network;

- the risk of growing competition between cities within the national and international networks of Cittaslow cities;

- the risk of losing the label of elite cities by cities which belong to the Cittaslow Network due to the increasing number of member cities (can all small cities be slow cities?);

- a barrier to the development of the tourism-related function in some Cittaslow cities is the poor accessibility to these sites (especially by airplane or train, but also by the poor infrastructure of roads);

- an unfavourable migration balance and demographic structure - the outflow of young people can result in a lower quality of social capital, less creativity and innovativeness in a city as well as the gradual disappearance of niche occupations (traditional crafts, cuisine) and the foregoing of local traditions by younger generations.

The identification of factors, determinants and barriers occurring in the development of slow cities in Poland can become an important element in a SWOT analysis, either carried out for individual member cities or for the entire Polish National Cittaslow Network. SWOT is an acronym composed of the first letters of the nouns, which are: Strengths, Weaknesses, Opportunities and Threats that refer to the characteristics of resources owned by an organisation (in this case, the network of cities) and its environment (Helms and Nixon, 2010, pp. 215-217). Weak and strong sides are internal characteristics, while opportunities and threats appear in the environment of analysed organisations (Gawroński, 2010, p. 171). Four categories of factors are generated by the intersection of these two divisions (Gierszewska and Romanowska, 2009, p. 190): external positive - opportunities, external negative - threats, internal positive - strengths, and internal negative - weaknesses. The factors and determinants of the development of the Polish Cittaslow network can be discussed according to this approach.

When making a SWOT analysis of the cities which belong to the Polish National Cittaslow Network, it is advisable to bear in mind the fact that member cities differ in population (there are cities with a population of fewer than 5000 residents and cities 
inhabited by over 20000 ) and in the duration of their membership in the network (from over 13 years to just a few months). In addition, it is necessary to consider the fact that the network is dispersed and varied in the socio-economic potential of cities. Examples of weaknesses and strengths as well as opportunities and threats regarding Polish slow cities, presented in this article, may not apply to all Cittaslow cities in Poland although they relate to a considerable number of these cities (see Table 3).

Table 3. SWOT analysis of the Polish National Cittaslow Network

\begin{tabular}{|c|c|}
\hline Strengths & Weaknesses \\
\hline 1 & 2 \\
\hline $\begin{array}{l}\text { Economic sphere: } \\
\text { - } \text { resources of the local labour market } \\
\text { - existing network of commerce and services } \\
\text { (including health resorts in some cities) } \\
\text { - social and administrative climate favourable } \\
\text { for investors } \\
\text { - collaborative promotional activities among } \\
\text { Cittaslow cities } \\
\text { Social sphere: } \\
\text { - young people willing to improve their } \\
\text { qualifications } \\
\text { - activities pursued by cultural institutions, } \\
\text { including the creation of culture } \\
\text { - developed social infrastructure } \\
\text { - growth of voluntary movement } \\
\text { relatively good quality of life } \\
\text { regularly held events promoting the image of } \\
\text { Cittaslow cities and network } \\
\text { Natural environment and spatial management: } \\
\text { - cities located in areas highly attractive to } \\
\text { tourists (e.g. in Warmia and Mazury) } \\
\text { - historical buildings and other sites appealing } \\
\text { to tourists, which create a potential for the } \\
\text { growth of tourism } \\
\text { - quality and diversity of the natural } \\
\text { environment }\end{array}$ & $\begin{array}{l}\text { Economic sphere: } \\
\text { - low level of cities' own capital resources } \\
\text { - } \text { private sector } \\
\text { - } \text { seasonality of tourist flow and a small number } \\
\text { of tourist products outside the high season } \\
\text { in which Cittaslow cities are situated (for } \\
\text { example Warmia and Mazury) in comparison } \\
\text { with other Polish regions } \\
\text { - low level of innovativeness among business } \\
\text { enterprises } \\
\text { - an insufficient use of the Cittaslow logo to } \\
\text { promote local products } \\
\text { Social sphere: } \\
\text { - high unemployment persisting in many cities } \\
\text { - people } \\
\text { little knowledge of the concept of the Slow } \\
\text { Environment slow city model } \\
\text { - an insufficient use of the environmental } \\
\text { - potential } \\
\text { poor state of municipal infrastructure and } \\
\text { transportation networks in some cities } \\
\text { low degree of using alternative energy sources }\end{array}$ \\
\hline Opportunities & 1110 cos \\
\hline $\begin{array}{l}\text { Economic sphere: } \\
\text { - construction and modernisation of the } \\
\text { infrastructure serving tourism in the region } \\
\text { where Cittaslow cities are located } \\
\text { - development of the tourism and hospitality } \\
\text { sector and economic promotion of the region } \\
\text { where Cittaslow cities are located }\end{array}$ & $\begin{array}{l}\text { Economic sphere: } \\
\text { - little interest among external investors to } \\
\text { invest in Cittaslow cities } \\
\text { - low level of entrepreneurship promoting local } \\
\text { products and services } \\
\text { - decreasing interest in slow tourism } \\
\text { - strong competition among cities (national and } \\
\text { global) }\end{array}$ \\
\hline
\end{tabular}


Table 3, cont.

\begin{tabular}{|c|c|}
\hline 1 & 2 \\
\hline $\begin{array}{l}\text { the role of the Cittaslow cities in the spatial } \\
\text { development taken into consideration (in the } \\
\text { national and regional policies) } \\
\text { - positive image of the international Cittaslow } \\
\text { network } \\
\text { - influx of investment capital } \\
\text { - growth of the circular economic concept } \\
\text { Social sphere: } \\
\text { - activisation of unemployed persons } \\
\text { - increasing knowledge of the idea of Slow } \\
\text { and more interest in slow tourism in the } \\
\text { country and globally } \\
\text { Natural environment and spatial management: } \\
\text { - sustainable development of cities } \\
\text { promotion of the natural values of Cittaslow } \\
\text { cities } \\
\text { implementation of investment projects aiming } \\
\text { to improve and maintain local cultural and } \\
\text { natural heritage }\end{array}$ & $\begin{array}{l}\text { - low level of absorption of EU funds } \\
\text { global economic crises } \\
\text { Social sphere: } \\
\text { - } \text { outflow of young people and employees with } \\
\text { highest qualifications to larger cities } \\
\text { - insufficient level of measures and solutions } \\
\text { preventing social exclusion } \\
\text { - deterioration of the quality of social capital } \\
\text { of the cities, declining level of local identity } \\
\text { Natural environment and spatial management: } \\
\text { - degradation of the environment } \\
\text { - lack of integrated environmental management } \\
\text { poorly developed technical infrastructure } \\
\text { (roads, railroads, transmission facilities) }\end{array}$ \\
\hline
\end{tabular}

Source: developed by the author, based on (Farelnik, 2019, pp. 130-135; Farelnik, 2020, pp. 267-287; Mazur-Belzyt, 2014, pp. 39-45; Ponadlokalny program rewitalizacji... 2019, pp. 44-45; Zadęcka, 2018, pp. 84-106).

The catalogue of factors influencing the development of Cittaslow cities in Poland is very long. Knowledge of these determinants, identified on local, regional, national, international and global levels, may be of key importance for the successful performance of an effective policy designed for the development of the Polish National Cittaslow Network; and thus, the development of Cittaslow cities. It is therefore necessary to make an in-depth analysis of the effect of these determinants on the development of the Cittaslow network, and this must involve a wide scope of empirical studies, using both quantitative methods, with publicly available statistical data on the social and economic development of Cittaslow cities, and (perhaps even more importantly) qualitative studies.

\section{Conclusion}

The identification of the factors, determinants and barriers in the development of Cittaslow cities, arising from the processes and events occurring both within these cities and in their closer and further surroundings, is extremely important to direct and perform the local policy of development. 
Among the major determinants influencing the development of the Cittaslow network in Poland, the following should be mentioned. Firstly, at local level there should be an active stance, the determination of authorities and local leaders to implement the vision of a slow city, knowledge of the philosophy of slow, and the approval of and identification with the concept of developing the city in the spirit of the slow city among the inhabitants. On a regional level there should be a regional policy that highlights the important role of Cittaslow cities in the region, and the type of collaboration between cities that belong to the network in regions and the country. Finally at the international and global level, there should be enhanced popularity of the slow philosophy and the Slow Food movement around the world with a positive image, the promotion of the Cittaslow Network in the world coinciding with global trends in world tourism (slow tourism, slow traveling) and a policy of the development of cities implemented at the EU level.

Beside the determinants and factors present at the local, regional, national, international and global levels, equally significant are other determinants underlying the implementation of the slow city model that are connected with the paradigm of the development of modern cities. It is especially important to know these factors and determinants which are closely connected with the characteristics of the adopted slow city model, and with the fact that a city functions within both the national and the international Cittaslow networks. Such knowledge should be employed by local authorities as well as local communities, entrepreneurs, local institutions, organisations and associations. The policy for the development of a city carried out prior to the city's joining the Cittaslow network should be verified so as to create suitable conditions for taking advantage of the opportunities arising from the adopted slow city development model and membership in the network (and certainly the new policy should not act against this model). Such a rational approach of local authorities will enable them to create an individual development pathway for their city, appropriate in terms of the city's potential and needs.

\section{References}

Atkinson, R., and Rossignolo, C. (2010). Cities and the 'soft side' of Europeanization: the role of urban networks. In A. Hamedinger, and A. Wolffhardt (Eds.), The Europeanization of cities - policies, urban change \& urban networks, Amsterdam: Techne Press.

Bagdziński, S. L. (1994). Lokalna polityka gospodarcza w okresie transformacji systemowej. Torun: Wydawnictwo Uniwersytetu Mikołaja Kopernika.

Batyk, I., and Woźniak, M. (2019). Benefits of belonging to the Cittaslow network in the opinion of residents of member cities. Economic and Regional Studies, 12(1), 56-67. DOI: 10.2478/ers-20190006

Blakely, E. J. (2009). The evolution of American (spatial) local and regional economic development policy and planning. In J. E. Rowe (Ed.), Theories of local economic development. Linking theory to practice. London: Routledge. 
Carp, J. (2012a). Cittaslow mean resilience. In T. Paquot, Y. Masson-Zanussi, and M. Stathopoulos (Eds.), Alterarchitectures Manifesto: observatory of innovative architectural and urban processes in Europe. Milan: Eterotopia.

Carp, J. (2012b). The study of slow. In B. E. Goldstein (Ed.), Collaborative resilience. Moving through crisis to opportunity. Cambridge: The MIT Press.

Chądzyński, J. (2007). Nowe koncepcje rozwoju - w kierunku rozwoju lokalnego. In J. Chądzyński, A. Nowakowska, and Z. Przygodzki, Region i jego rozwój w warunkach globalizacji. Warszawa: CeDeWu.

Churski, P. (2008). Czynniki rozwoju regionalnego i polityka regionalna w Polsce w okresie integracji $z$ Unia Europejska. Poznań: Uniwersytet im. Adama Mickiewicza w Poznaniu.

Cittaslow International Charter. (2017). Retrieved from https://www.cittaslow.org/sites/default/files/ content/page/files/257/charter_cittaslow_en_05_18.pdf

Cittaslow List. (2019). Retrieved from $\overline{\mathrm{h}}$ ttps://www.cittaslow.org/sites/default/files/content/page/ files/246/cittaslow_list_november_2019.pdf

Drobniak, A. (2015). Koncepcja urban resilience: narzędzie strategicznej diagnozy i monitoringu miast. Ruch Prawniczy, Ekonomiczny i Socjologiczny, (1), 119-143. DOI: 10.14746/rpeis.2015.77.1.7

Farelnik, E. (2018). Smart slow city jako hybrydowy model rozwoju współczesnych miast. Biuletyn KPZK PAN, (272), 137-146.

Farelnik, E. (2019). Fundusze europejskie jako źródło finansowania programów rewitalizacji w miastach Cittaslow. In A. Wojewnik-Filipkowska, and K. Szczepaniak (Eds.), Inwestycje i nieruchomości - wspótczesne wyzwania. Gdańsk: Wydawnictwo Uniwersytetu Gdańskiego.

Farelnik, E. (2020). Cooperation of slow cities as an opportunity for the development: an example of Polish National Cittaslow Network. Oeconomia Copernicana, 11(2), 267-287. DOI: 10.24136/ oc. 2020.011

Galibarczyk, M. (2017). Sieć Cittaslow jako wizerunkowy produkt turystyczny województwa warmińsko-mazurskiego. In E. Strzelecka (Ed.), Alternatywne modele rozwoju miast. Sieć miast Cittaslow. Łódź: Wydawnictwo Politechniki Łódzkiej.

Gawroński, H. (2010). Zarządzanie strategiczne w samorzadach lokalnych. Warszawa: Wolters Kluwer.

Gierszewska, G., and Romanowska, M. (2009). Analiza strategiczna przedsiębiorstwa. Warszawa: PWE.

Glaeser, E. L., Ponzetto, G. A. M., and Zou, Y. (2015). Urban networks: connecting markets, people, and ideas. National Bureau of Economic Research Working Papers, (21794), 1-61. DOI: 10.3386/ w21794

Gruszecka-Tieśluk, A. (2013). Sieć Cittaslow - strategią rozwoju małych miast w Polsce? Studia Ekonomiczne, 144(2), 383-393.

Hausner, J. (2019). Społeczna czasoprzestrzeń gospodarowania. W kierunku ekonomii wartości. Warszawa: Wydawnictwo Nieoczywiste.

Helms, M. M., and Nixon, J. (2010). Exploring SWOT analysis - where are we now? A review of academic research from the last decade. Journal of Strategy and Management, 3(3), 215-251. DOI: $10.1108 / 17554251011064837$

Honore, C. (2005). In praise of slowness: challenging the cult of speed. New York: HarperOne.

Hryniewicz, J. (2017). Czynniki lokalnego rozwoju gospodarczego - 20 lat później. Samorząd Terytorialny, (6), 5-23.

Jałowiecki, B. (1989). Rozwój lokalny. Warszawa: Wydawnictwo Uniwersytetu Warszawskiego.

Jaszczak, A., Morawiak, A., and Żukowska, J. (2020). Cycling as a sustainable transport alternative in Polish Cittaslow Towns. Sustainability, 12(5049). 1-23. DOI:10.3390/su12125049.

Korenik, S. (2013). Rozwój lokalny w świetle globalnych trendów ze szczególnym uwzględnieniem kryzysu. Prace Naukowe Uniwersytetu Ekonomicznego we Wrocławiu, (284), 31-40.

Kosiedowski, W. (2005). Wprowadzenie do teorii i praktyki rozwoju regionalnego i lokalnego. In W. Kosiedowski (Ed.), Samorząd terytorialny w procesie rozwoju regionalnego i lokalnego. Toruń: TNOiK. 
Krajowa polityka miejska 2023. (2015). Retrieved from http://prawo.sejm.gov.pl/isap.nsf/download. xsp/ WMP20150001235/O/M20151235.pdf

Leigh, N. G, and Blakely, E. (2013). Planning local economic development. Theory and practice. Los Angeles: SAGE.

Maik, W., and Parysek, J. (1978). Klasyfikacja i charakterystyka barier wzrostu w gospodarce przestrzennej. In B. Gruchman (Ed.), Bariery wzrostu w gospodarce przestrzennej. Warszawa: Komitet Przestrzennego Zagospodarowania Kraju PAN.

Mazur-Belzyt, K. (2014). Współczesne podstawy rozwoju małych miast na przykładzie sieci miast Cittaslow. Problemy Rozwoju Miast. Kwartalnik Naukowy Instytutu Rozwoju Miast. 11(3), 39-45.

Mierzejewska, L. (2009). Rozwój zrównoważony miasta. Zagadnienia poznawcze i praktyczne. Poznań: Wydawnictwo Naukowe Uniwersytetu Adama Mickiewicza w Poznaniu.

Międzynarodowy statut miast Cittaslow z dnia 12 maja 2017 r. (2017). Retrieved from https://cittaslowpolska.pl/images/ PDF/statut_cittaslow-12-maja--2017.pdf

Murzyn-Kupisz, M. (2012). Dziedzictwo kulturowe a rozwój lokalny. Kraków: Wydawnictwo Uniwersytetu Ekonomicznego w Krakowie.

Parysek, J. J. (1997). Podstawy gospodarki lokalnej. Poznań: Wydawnictwo Naukowe Uniwersytetu Adama Mickiewicza.

Parysek, J. J. (2018). Rozwój społeczno-gospodarczy oraz czynniki i uwarunkowania rozwoju. In P. Churski (Ed.), Teoretyczne i aplikacyjne wyzwania wspótczesnej geografii społeczno-ekonomicznej. Studia KPZK, (183), 37-56.

Pink, S., and Seale, K. (2017). Imagining and making alternative futures: slow cities as sites for anticipation and trust. In: M. Castells (Ed.), Another economy is possible: culture and economy in a time of crisis. Cambridge: Polity.

Ponadlokalny program rewitalizacji sieci miast Cittaslow województwa warmińsko-mazurskiego. (2019). Załącznik do Uchwały Walnego Zgromadzenia członków Stowarzyszenia „Polskie Miasta Cittaslow" nr 17/2019 z 30.08.2019 r.

Sikora-Fernandez, D. (2013). Koncepcja Smart City w założeniach polityki rozwoju miasta - polska perspektywa. Acta Universitatis Lodziensis, Folia Oeconomica, (290), 83-88.

Sikora-Fernandez, D. (2018), Smarter cities in post-socialist country: example of Poland. Cities, (78), 52-59. DOI: 10.1016/j.cities.2018.03.011

Strategia rozwoju turystyki województwa warmińsko-mazurskiego do roku 2025. Uchwała nr XVIII/ 425/16 Sejmiku Województwa Warmińsko-Mazurskiego z 28 czerwca 2016 r.

Strzelecka, E. (2018). Concept of resilience and development of small towns and rural area. Barometr Regionalny, 16(3), 121-130.

Sung, J., and Hoo, W. (2019). Investigating male consumers' lifestyle of health and sustainability (LOHAS) and perception toward slow fashion. Journal of Retailing and Consumer Services, 49, 120-128. DOI: 10.1016/j.jretconser.2019.03.018

Szołtysek, J. (Ed.). (2018). Jakość życia w mieście. Poglady interdyscyplinarne. Warszawa: CeDeWu.

Sztando, A. (2017). Ponadlokalna perspektywa zarzadzania strategicznego rozwojem lokalnym na przykładzie małych miast. Wrocław: Wydawnictwo Uniwersytetu Ekonomicznego we Wrocławiu.

Tocci, G. (2018). Slow and intelligent cities. When slow is also smart. In: M. Clancy (Ed.), Slow tourism, food and cities. London: Routledge.

Wierzbicka, W. (2020). Socio-economic potential of cities belonging to the Polish National Cittaslow Network. Oeconomia Copernicana, 11(1), 203-224. DOI: 10.24136/oc.2020.009

Wierzbicka, W., Farelnik, E., and Stanowicka, A. (2019). The development of the Polish National Cittaslow Network. Olsztyn Economic Journal, 14(1), 113-125. DOI: 10.31648/oej.3672

Wojtasiewicz, L. (1996). Ekonomiczne uwarunkowania rozwoju lokalnego. In J. J. Parysek (Ed.), Rozwój lokalny i lokalna gospodarka przestrzenna. Poznań: Bogucki Wydawnictwo Naukowe. 
Wojtasiewicz, L. (1997). Czynniki rozwoju lokalnego - nowe ujęcie metodologiczne. In W. Maik (Ed.), Problematyka rozwoju lokalnego w warunkach transformacji systemowej. Biuletyn KPZK PAN, (177), 7-18.

Yurtseven, H. R., and Kaya, O. (2011). Slow tourists: a comparative research based on Cittaslow principles. American International Journal of Contemporary Research, 1(2), 91-98.

Zadęcka, E. (2017). Rola marki sieci Cittaslow w budowaniu wizerunku małego miasta. Modern Management Review, 24(2), 159-172. DOI: 10.7862/rz.2017.mmr.48

Zadęcka, E. (2018). Slow city as a local development model. Economic and Regional Studies, 11(3), 84-106. DOI: 10.2478 /ers-2018-0027

Zawadzka, A. K. (2017). Making small towns visible in Europe: the case of Cittaslow Network - the strategy based on sustainable development. Transylvanian Review of Administrative Sciences, Special Issues, 90-106. DOI:10.24193/tras.SI2017.6

\section{UWARUNKOWANIA ROZWOJU SLOW CITIES W POLSCE}

Streszczenie: Celem badań była identyfikacja czynników, uwarunkowań i barier rozwoju slow cities w Polsce, ze szczególnym uwzględnieniem tych, które wiążą się z cechami modelu slow city i członkostwem w sieci Cittaslow. Przedmiotem badań były czynniki i uwarunkowania rozwoju miast należących do Polskiej Krajowej Sieci Miast Cittaslow. Analizę i wnioskowanie przeprowadzono głównie poprzez krytyczną analizę piśmiennictwa. Dokonano identyfikacji uwarunkowań i czynników rozwoju slow cities o charakterze lokalnym, regionalnym, krajowym, międzynarodowym i globalnym. Zwrócono uwagę na uwarunkowania implementacji modelu slow city związane ze współczesnym paradygmatem rozwoju miast, które to uwarunkowania powinny być uwzględniane w procesie zarządzania slow cities w Polsce.

Słowa kluczowe: Cittaslow, slow city, uwarunkowania rozwoju, małe miasta. 